\title{
Comparative evaluation of insecticidal properties of essential oils of some selected botanicals as bio-pesticides against Cowpea bruchid, Callosobruchus maculatus (Fabricius) [Coleoptera: Chrysomelidae]
}

Joy Ejemen Idoko ${ }^{1}$ and Kayode David Ileke ${ }^{2^{*}}$ (D)

\begin{abstract}
Background: The insecticidal activities of essential oils from seeds of five botanicals Tetrapleura tetraptera, Annona muricata, and Aframomum melegueta and leaves of Eucalyptus globulus and Ficus exasperata were evaluated as biopesticides against the storage pest of cowpea Callosobruchus maculatus (Fabricius). The oils were applied at the concentration of $1 \mathrm{ml} / \mathrm{kg}, 3 \mathrm{ml} / \mathrm{kg}$, and $5 \mathrm{ml} / \mathrm{kg}$ of cowpea seeds mixed evenly. The experiment was laid out in a completely randomized design. The parameters assessed include the percentage of mortality, oviposition, adult emergence, seeds damaged, weight loss, and germinability capacity of the protected seeds.

Results: The results from the study showed that the effectiveness of the essential oils was dependent on application rates and time of exposure. In the treated cowpea seeds, A. melegueta essential oil was the most effective with $50 \%$ lethal concentration (LC50) value of $2.42 \mathrm{ml} / \mathrm{kg}$ and $95 \%$ lethal concentration (LC95) value of $4.86 \mathrm{ml} / \mathrm{kg}$ when compared to the other treatments as indicated by the application rate which caused $50 \%$ and $95 \%$ mortality of cowpea beetles. A. melegueta essential oil at the concentration of $5 \mathrm{ml} / \mathrm{kg}$ achieved $100 \%$ mortality of C. maculatus at $48 \mathrm{~h}$ of application. Cowpea seeds treated with $5 \mathrm{ml} / \mathrm{kg}$ of E. globulus essential oil significantly reduced $(P<0.05)$ oviposition compared to the other treatments. Cowpea seeds treated with $5 \mathrm{ml} / \mathrm{kg}$ of $A$. muricata essential oil reduced adult emergence (3.67) and weight loss (0.59). The cowpea seeds treated with essential oils at different concentrations had no significant $(P>0.05)$ adverse effect on seed germination after 120 days of storage.
\end{abstract}

Conclusion: Based on the findings of this study, the essential oils could be explored as an alternative bio-pesticide to synthetic insecticide in the protection of stored cowpea against C. maculatus.

Keywords: Botanicals, Essential oils, Callosobruchus maculatus, Mortality, Adult emergence

\footnotetext{
* Correspondence: kdileke@futa.edu.ng

${ }^{2}$ Department of Biology, School of Science, Federal University of Technology,

PMB 704, Akure, Ondo State, Nigeria

Full list of author information is available at the end of the article
}

\section{Springer Open}

( ) The Author(s). 2020 Open Access This article is licensed under a Creative Commons Attribution 4.0 International License, which permits use, sharing, adaptation, distribution and reproduction in any medium or format, as long as you give appropriate credit to the original author(s) and the source, provide a link to the Creative Commons licence, and indicate if changes were made. The images or other third party material in this article are included in the article's Creative Commons licence, unless indicated otherwise in a credit line to the material. If material is not included in the article's Creative Commons licence and your intended use is not permitted by statutory regulation or exceeds the permitted use, you will need to obtain permission directly from the copyright holder. To view a copy of this licence, visit http://creativecommons.org/licenses/by/4.0/. 


\section{Background}

Cowpea (Vigna unguiculata (L.)) is a major staple food in sub-Saharan Africa; it is among the major sources of protein for human and livestock (Ileke et al. 2013). The high protein content of the seed makes it extremely valuable in tropical Africa where meat and fish are expensive for the teeming population (Olakojo et al. 2007) thus serving as an alternative to expensive sources of protein (Ileke et al. 2013). There are several reasons for the storage of agricultural produce in time of surplus in the tropical and sub-tropical regions in order to ensure food security. Among these agents militating against safe storage are arthropods which may include coleopterans and lepidopterans insect pest. A wide range of insect pests from the order Coleoptera attacks field crops up to storage (Udo 2011). Callosobruchus maculatus had been reported to cause $100 \%$ loss to cowpea seed during storage with a loss of 30 million US dollar in Nigeria (Udo and Epidi 2009). Cowpea bruchid, C. maculatus, is also known to cause substantial losses in terms of quality (nutritional loss) and quantity such as loss in market values, weight loss, and viability loss (Ofuya 2003; Ofuya et al. 2010). Approaches aimed at controlling attack by insect pests have relied heavily on the use of synthetic insecticides (Isman 2006). These synthetic chemicals are associated with shortcomings such as the emergence of resistant strains of pests, elimination of natural enemies and non-target species, environmental health hazard, and contamination of foods with chemicals (Ileke et al. 2013). Currently, research efforts are being focused on the use of plant biopesticides such as plant extracts which are tolerable than synthetic insecticides (Tamo 2012). Plant-based insecticides have been used as an alternative to synthetic chemical insecticides for pest management because botanicals pose no threat to the environment or to human health (Isman 2006; Maia and Moore 2011). Plant extracts and essential oils have traditionally been used to kill or repel stored product insects, more so many of them are believed to contain myriads of chemicals that could be insecticidal (Ileke and Adesina 2018). Hence, the current study was designed to evaluate the insecticidal activity of essential oils from seeds of Tetrapleura tetraptera, Annona muricata, and Aframomum melegueta and leaves of Ficus exasperata and Eucalyptus globulus for the control of C. maculatus on cowpea seeds.

\section{Methods}

\section{Study site}

The study was conducted in the Entomology Laboratory of the Department of Crop, Soil and Pest Management, The Federal University of Technology, Akure (FUTA), under ambient laboratory conditions of $28 \pm 3{ }^{\circ} \mathrm{C}$ temperature and $65 \pm 10 \%$ relative humidity.

\section{Culturing of $C$. maculatus}

The cowpea storage beetle C. maculatus was cultured on cowpea seeds "Ife Brown" a famous susceptible variety in Nigeria. The seeds were first cleaned of any impurities before disinfested in a deep freezer for 2 weeks. After removal from the freezer, the seeds were left to equilibrate at room temperature for $12-24 \mathrm{~h}$. About 50 pairs of C. maculatus adults were introduced into a glass jar containing $200 \mathrm{~g}$ of clean Ife Brown cowpea seeds. Thereafter, the setup culture was kept in an insect cage for the emergence of progeny. Insect cultures were recycled once a month to facilitate an adequate supply of insects during the study at mean temperature and relative humidity of $29.4{ }^{\circ} \mathrm{C}$ and $75.7 \%$, respectively.

\section{Source and identification of botanical materials}

Seeds of T. tetraptera, A. muricata, and A. melegueta and leaves of $F$. exasperata and E. globulus were obtained from the Teaching and Research Farm of the Federal University of Technology, Akure. The characteristics of the plant used are shown in Table 1. The identity of the botanicals was confirmed at the herbarium of the Crop, Soil and Pest Management Department of the Federal University of Technology, Akure. The seeds and the leaves were air-dried for 2 weeks in a well-ventilated shaded area from the sun to minimize the degradation of volatile compounds. The airdried plant materials were later milled into fine powder using Philips blender DC7104 model. Thereafter, the powders are stored separately in an air-tight polythene bag for a period of 2 days before extraction of the essential oils.

\section{Extraction of essential oils from botanicals}

The essential oils were extracted from the seeds of Tetrapleura tetraptera, Annona muricata, and Aframomum melegueta and leaves of Eucalyptus globulus and Ficus exasperata separately following the method of extraction described by Shaaya et al. (1977). The essential oils were extracted using volatile essential oil steam distillation apparatus which is made of $2000 \mathrm{ml}$ capacity distilling flask with a thick round condenser and graduated measuring tube with a collecting tap at the end. In carrying out the steam distillation process, $120 \mathrm{~g}$ each of the powders of the five different botanicals was weighed separately into a distilling flask and $300 \mathrm{ml}$ of water added; the apparatus was set up using a clamp on a heating mantle and heated for a period of $4 \mathrm{~h}$. The essential oil deposited on the water was then collected through the attached graduated measuring tube by opening the tap. The extraction was carried out throughout the period of the experiment to facilitate a steady supply of essential oil for the study. The essential oils extracted were collected separately inside a bottle with a tight-fitted cover, and each of the bottles was labeled with the names of each essential oil. Thereafter, the bottles containing the oils were stored in a cool refrigerator at a temperature of $4{ }^{\circ} \mathrm{C}$ until use. 
Table 1 Plant essential oils evaluated for insecticidal properties against Callosobruchus maculatus

\begin{tabular}{llll}
\hline Scientific name & Common name & Family & Plant part used \\
\hline Tetrapleura tetraptera & Aridan & Mimosaceae & Seed \\
Annona muricata & Soursop & Annonaceae & Seed \\
Aframomum melegueta & Alligator pepper & Zingiberaceae & Seed \\
Ficus exasperate & Sandpaper tree & Moraceae & Leaf \\
Eucalyptus globulus & Southern blue gum & Myrtaceae & Leaf \\
\hline
\end{tabular}

\section{Bioassay}

Essential oils extracted from the seeds of T. tetraptera, $A$. muricata, and A. melegueta and leaves of $F$. exasperata and E. globulus were evaluated for the control of $C$. maculatus at the rate of $1 \mathrm{ml} / \mathrm{kg}, 3 \mathrm{ml} / \mathrm{kg}$, and $5 \mathrm{ml} / \mathrm{kg}$ of cowpea seeds which form the bulk seeds adopting the procedure described by Lale (1995). Ten freshly emerged adults ( 5 males and 5 females) of $C$. maculatus $(0-48 \mathrm{~h}$ old) were used to infest $20 \mathrm{~g}$ of cowpea seeds weighed from the treated bulk seeds, and a control was also set up containing seeds that were not treated with essential oils. The experiment was replicated three times. Insect mortality was monitored at 12,24 , and $48 \mathrm{~h}$ for C. maculatus. Thereafter, the number of eggs laid on cowpea seeds were counted and recorded, seeds were examined for adult emergence at 21 days after oviposition, and the number of adults that emerged were counted and recorded. Ten days after adult emergence, the cowpea seeds were reweighed to obtain the seed weight loss as a result of larva consumption. Seed germination test was carried out on the seeds. Ten seeds from each treatment were separately and randomly selected. The seeds were placed in Petri dishes containing moistened filter paper (Whatman no. 1) and arranged in the laboratory shelf for emergence. From 3 to 7 days, the number of germinated seedlings from each Petri dish was counted and recorded.

\section{Data analysis}

Data on percentage mortality, seed weight loss, and percentage seed germinations were arcsine transformed while data on the number of eggs laid were square-root transformed before subjected to analysis of variance (ANOVA). Where the analysis of variance test indicated significant differences between treatments, Tukey's test was used to separate means at $5 \%$ level of probability. Data on mortality was subjected to probit analysis to determine the fiducial limit of the essential oil that can cause $50 \%$ and $90 \%$ mortality.

\section{Results}

\section{Mortality of adult C. maculatus in treated cowpea seeds} with plant essential oils

The percentage mortality of $C$. maculatus on cowpea seeds treated with different concentrations of the essential oils from botanicals at 12,24 , and $48 \mathrm{~h}$ is presented in Table 2. At $12 \mathrm{~h}$, adult mortality of C. maculatus was significantly higher $(P<0.05)$ on cowpea seeds treated with essential oils than the control treatment. Mortality of adult $C$. maculatus increased with the increase in the rate of the essential oil and time of exposure. However, the result showed that there were no significant differences in adult mortality of $C$. maculatus on cowpea seeds treated with the essential oils of the five botanicals. Mortality was highest (26.67\%) on cowpea seeds treated with $5 \mathrm{ml} / \mathrm{kg}$ of $A$. melegueta essential oil and the lowest (6.67\%) mortality was observed on seeds treated with 1 $\mathrm{ml} / \mathrm{kg}$ of $T$. tetraptera essential oil. At $24 \mathrm{~h}$, the percentage mortality of $C$. maculatus on treated seeds was significantly higher than control. It was similarly observed that the mortality of adult C. maculatus increased with the increase in the concentration of the essential oils. At $5 \mathrm{ml} / \mathrm{kg}$ concentration of $F$. exasperate essential oil, adult mortality of $C$. maculatus was significantly higher compared to other treatments. At $48 \mathrm{~h}$ of application, the result shows that mortality of adult $C$. maculatus was significantly higher $(P<0.05)$ on the treated seeds than the control treatment. Also, adult mortality of $C$. maculatus on cowpea seeds treated with different concentrations of the essential oil differs significantly. At $3 \mathrm{ml} / \mathrm{kg}$ concentration of the essential oil, adult mortality was $50 \%$ and above on cowpea seeds treated with $A$. melegueta (76.67\%), A. muricata (50\%), F. exasperata (60\%), and T. tetraptera (66.67\%) except for E. globulus where mortality was $40 \%$. Adult mortality of $100 \%$ was recorded on seeds treated with A. melegueta and 90\% with T. tetraptera at $5 \mathrm{ml} / \mathrm{kg}$ concentration.

\section{Effect of plant essential oil treatment on oviposition, adult emergence, and weight loss}

The mean number of eggs laid, the percentage of emerged adults, and weight loss caused by $C$. maculatus on cowpea seeds treated with essential oils and the control differ significantly (Table 3). Irrespective of the essential oil treatment, eggs laid by female $C$. maculatus on treated cowpea seeds were significantly lower $(P<$ $0.05)$ compared to the control. The lowest value of eggs laid was recorded on cowpea seeds treated with $5 \mathrm{ml} / \mathrm{kg}$ of essential oil, while the highest number of eggs laid was observed on cowpea seeds treated with $1 \mathrm{ml} / \mathrm{kg}$ of essential oil. Also, in Table 3, the results showed that cowpea seeds treated with essential oils significantly 
Table 2 Percentage mortality of C. maculatus on cowpea seeds treated with different concentrations of essential oil from botanicals at different time intervals

\begin{tabular}{|c|c|c|c|c|c|}
\hline Conc. (ml) & Aframomum melegueta & Annona muricata & Eucalyptus globules & Ficus exasperate & Tetrapleura tetraptera \\
\hline \multicolumn{6}{|l|}{$12 \mathrm{~h}$} \\
\hline 0 & $0.00^{c}$ & $0.00^{c}$ & $0.00^{c}$ & $0.00^{c}$ & $0.00^{c}$ \\
\hline 1 & $13.33^{\mathrm{ab}}$ & $13.33^{\mathrm{ab}}$ & $13.33^{\mathrm{ab}}$ & $16.67^{\mathrm{ab}}$ & $6.67^{\mathrm{ab}}$ \\
\hline 3 & $20.00^{\mathrm{a}}$ & $16.67^{\mathrm{a}}$ & $16.67^{\mathrm{a}}$ & $20.00^{\mathrm{a}}$ & $16.67^{\mathrm{a}}$ \\
\hline 5 & $26.67^{\mathrm{a}}$ & $16.67^{\mathrm{a}}$ & $20.00^{a}$ & $20.00^{a}$ & $20.00^{a}$ \\
\hline \multicolumn{6}{|l|}{$24 \mathrm{~h}$} \\
\hline 0 & $0.00^{\mathrm{a}}$ & $0.00^{c}$ & $0.00^{c}$ & $0.00^{c}$ & $0.00^{c}$ \\
\hline 1 & $16.67^{b}$ & $20.00^{b}$ & $20.00^{\mathrm{b}}$ & $23.33^{\mathrm{ab}}$ & $16.67^{b}$ \\
\hline 3 & $33.33^{\mathrm{a}}$ & $23.33^{\mathrm{ab}}$ & $23.33^{\mathrm{ab}}$ & $30.00^{a}$ & $23.33^{\mathrm{ab}}$ \\
\hline 5 & $40.00^{\mathrm{a}}$ & $33.33^{\mathrm{a}}$ & $40.00^{\mathrm{a}}$ & $43.33^{\mathrm{a}}$ & $36.67^{\mathrm{a}}$ \\
\hline \multicolumn{6}{|l|}{$48 \mathrm{~h}$} \\
\hline 0 & $3.33^{c}$ & $0.00^{c}$ & $3.33^{c}$ & $3.33^{c}$ & $0.00^{c}$ \\
\hline 1 & $26.67^{b}$ & $30.00^{\mathrm{b}}$ & $33.33^{b}$ & $40.00^{b}$ & $30.00^{b}$ \\
\hline 3 & $76.67^{\mathrm{ab}}$ & $54.00^{\mathrm{ab}}$ & $52.00^{\mathrm{ab}}$ & $60.00^{\mathrm{ab}}$ & $66.67^{\mathrm{ab}}$ \\
\hline 5 & $100.00^{\mathrm{a}}$ & $80.00^{\mathrm{a}}$ & $73.33^{\mathrm{a}}$ & $70.00^{\mathrm{a}}$ & $90.00^{\mathrm{a}}$ \\
\hline
\end{tabular}

Means followed by the same letter along the column were not significantly different at $5 \%$ using Tukey's test

Table 3 Effects of essential oils on the insect biology and seed weight loss by Callosobruchus maculatus

\begin{tabular}{|c|c|c|c|c|}
\hline Botanicals & Dose $(\mathrm{ml})$ & Oviposition & Adult emergence & Weight loss (\%) \\
\hline \multirow[t]{4}{*}{ Aframomum melegueta } & 0 & $180.33^{\mathrm{a}}$ & $62.67^{a}$ & $7.73^{\mathrm{a}}$ \\
\hline & 1 & $125.00^{\mathrm{ab}}$ & $37.33^{\mathrm{ab}}$ & $4.32^{\mathrm{b}}$ \\
\hline & 3 & $91.00^{\mathrm{b}}$ & $24.33^{b}$ & $2.98^{\mathrm{b}}$ \\
\hline & 5 & $92.67^{b}$ & $14.33^{c}$ & $1.91^{\mathrm{c}}$ \\
\hline \multirow[t]{4}{*}{ Ficus exasperate } & 0 & $168.00^{\mathrm{a}}$ & $68.67^{\mathrm{a}}$ & $9.40^{\mathrm{a}}$ \\
\hline & 1 & $155.67^{\mathrm{ab}}$ & $38.67^{\mathrm{ab}}$ & $4.89^{b}$ \\
\hline & 3 & $140.33^{b}$ & $29.33^{b}$ & $3.40^{\mathrm{b}}$ \\
\hline & 5 & $129.33^{c}$ & $18.00 \mathrm{c}$ & $2.48^{\mathrm{b}}$ \\
\hline \multirow[t]{4}{*}{ Tetrapleura tetraptera } & 0 & $165.67^{\mathrm{a}}$ & $68.67^{a}$ & $7.62^{\mathrm{a}}$ \\
\hline & 1 & $103.67^{b}$ & $38.67^{b}$ & $3.98^{\mathrm{b}}$ \\
\hline & 3 & $105.67^{\mathrm{b}}$ & $29.33^{b}$ & $2.33^{b}$ \\
\hline & 5 & $105.67^{b}$ & $18.00^{\mathrm{b}}$ & $1.08^{c}$ \\
\hline \multirow[t]{4}{*}{ Annona muricata } & 0 & $152.33 a$ & $61.00^{\mathrm{a}}$ & $7.55^{\mathrm{a}}$ \\
\hline & 1 & $143.67^{\mathrm{ab}}$ & $34.67^{\mathrm{ab}}$ & $4.53^{\mathrm{ab}}$ \\
\hline & 3 & $120.67^{b}$ & $22.00^{\mathrm{b}}$ & $2.93^{b}$ \\
\hline & 5 & $117.67^{b}$ & $3.67^{c}$ & $0.59^{c}$ \\
\hline \multirow[t]{4}{*}{ Eucalyptus globules } & 0 & $159.33^{\mathrm{a}}$ & $62.33^{\mathrm{a}}$ & $8.69^{a}$ \\
\hline & 1 & $107.33^{\mathrm{ab}}$ & $32.67^{b}$ & $4.05^{\mathrm{ab}}$ \\
\hline & 3 & $115.33^{\mathrm{ab}}$ & $23.67^{\mathrm{bc}}$ & $2.30^{\mathrm{b}}$ \\
\hline & 5 & $85.67^{b}$ & $15.33^{c}$ & $2.13^{b}$ \\
\hline
\end{tabular}


reduced $(P<0.05)$ emergence of adults compared to the untreated control. Similarly, cowpea seeds treated with $5 \mathrm{ml} / \mathrm{kg}$ of essential oils recorded the lowest adult emergence, while cowpea seeds treated with $1 \mathrm{ml} / \mathrm{kg}$ of the essential oils recorded the highest adult emergence compared to other treatments involving $3 \mathrm{ml} / \mathrm{kg}$ and $5 \mathrm{ml} / \mathrm{kg}$. Generally, it was observed that the number of eggs laid and adult emergence decreased significantly with the increase in rates of the essential oil and exposure period. The percentage weight loss of cowpea seeds treated with essential oils was significantly lower $(P<0.05)$ when compared to untreated control. Irrespective of the plant materials, cowpea seeds treated with $5 \mathrm{ml} / \mathrm{kg}$ of essential oil achieved the lowest seed weight loss, while cowpea seeds treated with $1 \mathrm{ml} / \mathrm{kg}$ of essential oils had the highest seed weight loss and were significantly different $(P<0.05)$ compared to other treatments involving $3 \mathrm{ml} / \mathrm{kg}$ and $5 \mathrm{ml} / \mathrm{kg}$.

\section{Lethal dose (LD) of plant essential oils against C. maculatus}

The result of lethal concentrations of essential oils $\left(\mathrm{LC}_{50}\right.$ and $\mathrm{LC}_{95}$ ) on $C$. maculatus at $48 \mathrm{~h}$ of exposure is presented in Table 4. The essential oil of A. melegueta fiducial limit 1.80-3.11 and 3.93-5.12 was the most effective in causing adult mortality with $\mathrm{LC}_{50}$ value of $2.42 \mathrm{ml} / \mathrm{kg}$ and $\mathrm{LC}_{95}$ value of $4.86 \mathrm{ml} / \mathrm{kg}$ when compared to other treatment as indicated by the application rate which caused $50 \%$ and $95 \%$ mortality of cowpea beetles, while E. globulus with fiducial limit $2.82-4.96$ and 5.34-8.32 appeared to be least effective in causing adult mortality with $\mathrm{LC}_{50}$ value of $3.91 \mathrm{ml} / \mathrm{kg}$ and $\mathrm{LC}_{95}$ value of $6.01 \mathrm{ml} / \mathrm{kg}$ compared to other treatments.

\section{Effect of plant essential oil treatment on the percentage of germination}

Table 5 shows the germination percentage for cowpea seeds treated with different rates of essential oils. Cowpea seed treated with essential oils at different rates had no significant adverse effect on seed germination after 120 days of storage. Though $100 \%$ seed germination was almost achieved for all the treatment concentration, however, from the result, it was observed that $1 \mathrm{ml} / \mathrm{kg}$ and $3 \mathrm{ml} / \mathrm{kg}$ produced $100 \%$ seed germination, but the percentage of seeds that germinated starts to decrease at $5 \mathrm{ml} / \mathrm{kg}$ treatment rate.

\section{Discussion}

Plant-based insecticides have been used as a substitute to synthetic chemical insecticides that pose environmental health hazard for insect pest control because phytopesticides comes with no threat to the environment and human health (Isman 2006; Maia and Moore 2011). Ileke and Adesina (2018) reported that botanical oils contained numerous phytochemicals that could be insecticidal in nature.

The result of this study has unequivocally showed that essential oils from seeds of A. melegueta, A. muricata, and T. tetraptera and leaves of E. globulus and F. exasperata possessed insecticidal properties at varying degrees. Generally, the effects of essential oils to cause mortality of adult C. maculatus increased with the increase in treatment rates and time of exposure. A. melegueta essential oil was the most effective with $\mathrm{LC}_{50}$ value of $2.42 \mathrm{ml} / \mathrm{kg}$ and $\mathrm{LC}_{95}$ value of $4.86 \mathrm{ml} / \mathrm{kg}$ when compared to other treatments as indicated by the application rate which caused 50\% and 95\% mortality of cowpea beetles. A. melegueta essential oil caused above $50 \%$ insect mortality at the rates of $3 \mathrm{ml} / \mathrm{kg}(76.67 \%)$ and also at the rates of $5 \mathrm{ml} / \mathrm{kg}$ achieved complete (100\%) mortality at $48 \mathrm{~h}$. A similar observation has been reported by Adesina et al. (2015) that A. melegueta seed extract exerted $85 \%$ mortality at $120 \mathrm{~h}$ post-infestation against C. maculatus and can be used in formulating ecofriendly herbal insecticide. The high mortality caused by essential oils may be due to the choking smell of the essential oils which must have disrupted the normal respiratory process of the insects. Keita et al. (2000) reported similar results while working with various essentials oils on C. maculatus; Raja and John (2008) also reported an increase in the mortality of adult C. maculatus with increased rates of different volatile oils as the time of exposure increased.

Essential oils played an important role in reducing oviposition by female beetles, adult emergence, and percentage weight loss. The lowest value of eggs laid was recorded on cowpea seeds treated with $5 \mathrm{ml} / \mathrm{kg}$ of $E$. globulus essential oil compared to other treatments. This

Table 4 Lethal concentrations ( $L C_{50}$ and $L C_{95}$ ) of essential oils on C. maculatus at $48 \mathrm{~h}$ of exposure

\begin{tabular}{lllllllll}
\hline Botanicals & Slope $\pm \mathrm{SE}$ & Intercept $\pm \mathrm{SE}$ & $x^{2}$ & $\mathrm{LC}_{50}$ & $95 \% \mathrm{FL}$ & $\mathrm{LC}_{95}$ & $95 \% \mathrm{FL}$ & $P$ value \\
\hline Aframomum melegueta & $0.96 \pm 0.13$ & $-0.40 \pm 0.10$ & 5.14 & 2.42 & $1.80-3.11$ & 4.86 & $3.93-5.12$ & 0.00 \\
Annona muricata & $0.81 \pm 0.11$ & $-0.32 \pm 0.12$ & 4.01 & 3.00 & $2.16-3.76$ & 5.52 & $4.81-6.24$ & 0.01 \\
Eucalyptus globulus & $0.32 \pm 0.10$ & $-0.61 \pm 0.11$ & 8.13 & 3.91 & $2.82-4.96$ & 6.01 & $5.34-8.32$ & 0.00 \\
Ficus exasperate & $0.48 \pm 0.11$ & $-0.42 \pm 0.14$ & 3.11 & 2.78 & $1.95-3.24$ & 5.93 & $5.05-7.14$ & 0.00 \\
T. tetraptera & $0.71 \pm 0.12$ & $-0.28 \pm 0.12$ & 6.16 & 2.51 & $1.86-3.18$ & 5.16 & $4.12-6.85$ & 0.01 \\
\hline
\end{tabular}

$x^{2}$ chi-square, SE Standard error, LC Lethal concentration, FL Fiducial limits 
Table 5 Effect of essential oils on the germination of cowpea seeds after 120 days

\begin{tabular}{lllll}
\hline Botanicals & \multicolumn{4}{l}{ Concentration $(\mathrm{ml})$} \\
\cline { 2 - 5 } & 0 & 1 & 3 & 5 \\
\hline Aframomum melegueta & $80^{\mathrm{a}}$ & $100^{\mathrm{a}}$ & $100^{\mathrm{a}}$ & $90^{\mathrm{a}}$ \\
Annona muricata & $85^{\mathrm{a}}$ & $100^{\mathrm{a}}$ & $100^{\mathrm{a}}$ & $90^{\mathrm{a}}$ \\
Eucalyptus globulus & $85^{\mathrm{a}}$ & $100^{\mathrm{a}}$ & $100^{\mathrm{a}}$ & $100^{\mathrm{a}}$ \\
Ficus exasperate & $80^{\mathrm{a}}$ & $100^{\mathrm{a}}$ & $100^{\mathrm{a}}$ & $90^{\mathrm{a}}$ \\
Tetrapleura tetraptera & $85^{\mathrm{a}}$ & $100^{\mathrm{a}}$ & $100^{\mathrm{a}}$ & $100^{\mathrm{a}}$ \\
\hline
\end{tabular}

Means followed by the same letter along the column were not significantly different at $5 \%$ using Tukey's test

present study also shows that E. globulus significantly reduced oviposition as the rate of the essential oils applied to cowpea seeds increased. Thus, the oils from the leaves of $E$. globulus excerted oviposition deterrent effect on $C$. maculatus. Also, it was visually observed that the few eggs laid by C. maculatus were unable to glue to the surface of cowpea seeds due to the obstruction effects of the oil. This rendered the cowpea seeds unacceptable to the beetle as they showed oviposition preference for untreated cowpeas. Idoko (2016) opined that the commercial use of plant products as anti-ovipositant against $C$. maculatus is undoubtedly an alternative insecticide. In addition, cowpea seeds treated with $5 \mathrm{ml} / \mathrm{kg}$ of $A$. muricata essential oil reduced adult emergence (3.67). Thang et al. (2013) reported that $A$. muricuta volatile oil consists of active compounds and acids with contact and growth inhibition properties. This growing body of experimental proof supports the idea that $A$. muricata shows insecticidal activity against assorted types of insects. Adeoye and Ewete (2010) reported that A. muricata seed extract significantly decreased the oviposition and emerged adults of $C$. maculatus and appeared to be a promising protectant against the respective insect in stored cowpea.

The number of emerged adults was significantly lower on cowpea seeds treated with essential oils at all rates, because of adult mortality and reduced oviposition which consequently reduced adult's emergence at all rates applied. Ketoh et al. (2005) observed that essential oil extracted from Cymbopogon schoenanthus was effective in lowering the population of C. maculatus; the reduction was high enough to prevent the emergence of larva stage. The reproductive potential of $C$. maculatus, which were exposed to essential oils, reduced significantly. A similar observation was reported by Manzoomi et al. (2010) that various essential oils were highly effective in causing adult mortality, reducing oviposition, adult emergence, and reduced weight loss caused by $C$. maculatus. Weight loss was significantly reduced in cowpea seeds treated with $5 \mathrm{ml} / \mathrm{kg}$ of $A$. muricata essential oil (0.59); this could be as a result of inability of the beetle to oviposit on the seeds, or few eggs laid were unable to hatched into larva or adult stages thereby prevented the holing of the protected seeds (Janzen 1977). The effect of essential oils on insect development has been caused by phytochemical and insecticidal properties of the plant extract (Nivea et al. 2013).

The results on germination on seeds treated with the essential oils have further substantiated the report of many other workers (Kritzinger et al. 2002; Chaubey 2013; Keita et al. 2002) that essential oil has no adverse effect on germination of treated seeds. The five plant essential oils examined for treatment effect on seed germination achieved $100 \%$ seed germination at treatment concentration of $1 \mathrm{ml} / \mathrm{kg}$ and $3 \mathrm{ml} / \mathrm{kg}$. Consistent with the report of this study, Dinesh and Deepshikha (2012) examined four plant oils for treatment effect on cowpea seed germination and reported that different oils at 1 $\mathrm{ml} / \mathrm{kg}$ and $3 \mathrm{ml} / \mathrm{kg}$ seed had no significant adverse effect on seed germination at all concentrations. However, it was also observed in this study that $5 \mathrm{ml} / \mathrm{kg}$ treatment concentrations of essential oil reduced the germination of the seed thereby preventing $100 \%$ germination in most of the plant materials used. Similar to the observation in this study, Qi and Burkholder (1981) reported diminishing germination capabilities in wheat when $5 \mathrm{ml}$ and $10 \mathrm{ml}$ of vegetable oil were used in treated wheat grain. From the result of this study, it is opined that the essential oils can be used at lower concentration in preserving cowpea seeds intended for planting.

\section{Conclusions}

Based on the findings from these results, the essential oils used in this study could be explored as an alternative bio-pesticide to synthetic insecticide in the protection of stored cowpea against $C$. maculatus. The essential oils from $A$. melegueta seed were highly effective in causing high mortality of $C$. maculatus, while $E$. globulus leaf essential oil reduced oviposition and $A$. muricata seed essential oil reduced adult emergence and weight loss of cowpea seeds by C. maculatus. F. exasperata showed to be the least effective in controlling $C$. maculatus in all the parameters assessed. Also, in order to avoid diminishing germination of cowpea seed, the application of the oils at a rate of $5 \mathrm{ml} / \mathrm{kg}$ or more should be discouraged in storing seeds intended for planting.

\footnotetext{
Acknowledgements

The authors thank The Laboratory Assistants of Research Laboratory, Crop, Soil and Pest Management Department, Federal University of Technology, Akure, for their assistance during the extraction process.
}

Authors' contributions

JEl conceived and designed the study and reviewed the manuscript. JEl and $\mathrm{KDI}$ collected data on insect bioassay experiments. KDI analyzed all data 
collected, search references, and manuscript draft. All authors read and approved the final manuscript.

\section{Funding}

The authors declare that no fund was received from anybody in carrying out this study. This research study was funded collectively by the authors.

\section{Availability of data and materials}

Data collected and analyzed during the current study are available from the corresponding author on reasonable request.

\section{Ethics approval and consent to participate}

Not applicable.

\section{Consent for publication}

Not applicable.

\section{Competing interests}

The authors declare that they have no competing interests.

\section{Author details}

'Department of Crop, Soil and Pest Management, School of Agriculture and Agricultural Technology, Federal University of Technology, PMB 704, Akure, Ondo State, Nigeria. ${ }^{2}$ Department of Biology, School of Science, Federal University of Technology, PMB 704, Akure, Ondo State, Nigeria.

Received: 19 April 2020 Accepted: 8 July 2020

Published online: 16 July 2020

\section{References}

Adeoye O, Ewete F (2010) Potentials of Annona muricata Linnaeus (Annonaceae) as a botanical insecticide against Callosobruchus maculatus Fabricius (Coleoptera: Bruchidae). J Agricul For Soc Sci 8:147-151

Adesina JM, Jose AR, Rajashaker Y, Afolabi LA (2015) Entomo Toxicity of Xylopia aethiopica and Aframomum melegueta in suppressing oviposition and adult emergence of Callasobruchus maculatus (Fabricus) (Coleoptera: Chrysomelidae) infesting stored cowpea seeds. Jord J Biol Sci 8(4):263-268

Chaubey MK (2013) Biological Activity of Zingiber officinale and Piper cubeba essential oils against pulse beetle, Callosobruchus chinensis. Pak J Biol Sci 16(11):517-523

Dinesh L, Deepshikha VR (2012) Efficacy of application of four vegetable oils as grain protectant against the growth and development of Callosobruchus maculatus and on its damage. Adv Biores 3(2):55-59

Idoko JE (2016) Evaluation of some paddy rice products as anti-ovipositant against Callosobruchus maculatus Fabricius. (Coleoptera: Chrysomelidae). Appl Trop Agricul 21(1):133-137

lleke KD, Adesina JM (2018) Biochemical toxicity of two termicides, Xylopia aethiopica and Piper guineense Seeds on Termites, Macrotermes subhyalinus Smeathman (Isoptera: Termitidae) on Albino rat. Utt Prad J Zoo 38(3):84-94

lleke KD, Odeyemi OO, Ashamo MO (2013) Response of cowpea bruchid, Callosobruchus maculatus (Fabr.) [Coleoptera: Chrysomelidae] to Cheese Wood, Alstonia boonei De Wild stem bark oil extracted with different solvents. Arc Phytopath Pla Protect 46(11):1357-1370

Isman MB (2006) Botanical insecticide deterrents and repellants in modern agriculture and on increasingly regulated world. Ann Rev Entomol 51:45-66

Janzen DH (1977) How southern cowpea weevil larvae (Bruchidae Callosobruchus maculatus) die on non-host seeds. Ecol 8:921-927

Keita SM, Vincent C, Schmidt JP, Arnason JT (2000) Insecticidal effects of Thuja occidentalis (Cupressaceae) essential oil on Callosobruchus maculatus [Coleoptera: Bruchidae]. Cana J Plt Sci 8(1):173-177

Keita SM, Vincent C, Schmidt JP, Arnason JT (2002) Effect of various essential oils on Callosobruchus maculatus (F.) (Coleoptera: Bruchidae). J Stor Prod Res 36(4):355-364

Ketoh GK, Honore K, Koumaglo O, Isabelle A, Glitho IA (2005) Inhibition of Callosobruchus maculatus (F.) (Coleoptera: Bruchidae) development with essential oil extracted from Cymbopogon schoenanthus L. Spreng. (Poaceae) and the wasp Dinarmus basalis (Rondani) (Hymenoptera: Pteromalidae). J Stor Prod Res 41(4):363-371

Kritzinger Q, Aveling TAS, Marasas WFO (2002) Effect of essential plant oils on storage fungi, germination and emergence of cowpea seeds. Seed Sci Technol 30:609-619
Lale NES (1995) An overview of the use of plant products in the management of stored products coleopteran in the tropics. Postharvt N Infor 6:69-75

Maia MF, Moore SJ (2011. PubMed https://www.ncbi.nlm.nih.gov/pubmed/21411 012) Plant as repellents: a review of their efficacy, development and testing Malaria. https://doi.org/10.1186/1475-2875-10-S1-S11

Manzoomi N, Ganbalani GN, Dastjerdi HR, Fathi SAA (2010) Fumigant toxicity of essential oils of Lavandula officinalis, Artemisia dracunculus and Heracleum persicum on the adults of Callosobruchus maculatus (Coleoptera: Bruchidae). Mun Entomol Zoo 5:118-122

Nivea MSG, De Oliveira JV, Navarro DMAF, Dutra KA, Silva WA, Wanderley MJA (2013) Contact and fumigant toxicity and repellency of Eucalyptus citriodora Hook., Eucalyptus staigeriana F., Cymbopogon winterianus Jowitt and Foeniculum vulgare Mill. essential oils in the management of Callosobruchus maculatus (Fabr.) (Coleoptera: Chrysomelidae, Bruchinae). J Stor Prod Res 54: $41-47$

Ofuya TI (2003) Beans, insects and man. Inaugural lecture series 35. The Federal University of Technology, Akure, Nigeria, p 45

Ofuya TI, OF O, Ogunsola OJ (2010) Fumigation toxicity of crushed bulbs of two Allium species to Callosobruchus maculatus (Fabr.) (Coleoptera: Bruchidae). Chil J Agricul Res 70(30):510-514

Olakojo SA, Ayanwole JA, Obasemola VI (2007) Laboratory screening of seeds of cowpea cultivars for tolerance to cowpea beetle in hot-humid environment. Amer-Eura J Agricul Environ Sci 2(5):528-533

Qi YT, Burkholder WE (1981) Protection of stored wheat from the granary weevil by vegetable oils. J Eco Entomol 74:502-505

Raja N, John WS (2008) Impact of volatile oils of plants against the cowpea beetle Callosobruchus maculatus (FAB.) (Coleoptera: Bruchidae). Int J Integr Biol 2(1):62-64

Shaaya E, Kostjukovski M, Eilberg J, Sukprakarn C (1977) Plant oils as fumigants and contact insecticides for the control of stored-product insects. J Stor Prod Res 33(1):7-15

Tamo M (2012) Farmers in Africa should switch to biopesticides. SciDev http:// paepard.blogspot.com/2012/04/farmers-in-africa-should-switch-to.html. Accessed 19 Dec 2019

Thang T, Dai D, Hoi T, Ogunwande I (2013) Study on the volatile oil contents of Annona glabra L., Annona squamosa L., Annona muricata L. and Annona reticulata L., from Vietnam. Nat Prod Res 27:1232-1236

Udo IO (2011) Potentials of Zanthoxylum xanthoxyloides (Lam.) for the control of stored product insect pests. J Stor Prod Postharv Res 2(3):40-44

Udo IO, Epidi TT (2009) Biological effect of ethanolic extract fractions of Ricinodendron heudelotii (Baill) Pierre ex Pax against Sitophilus zeamais and Callosobruchus maculatus Fabricius on stored grains. Afri J Agricul Res 4(10): 1080-1085

\section{Publisher's Note}

Springer Nature remains neutral with regard to jurisdictional claims in published maps and institutional affiliations.

\section{Submit your manuscript to a SpringerOpen ${ }^{\bullet}$ journal and benefit from:}

- Convenient online submission

- Rigorous peer review

- Open access: articles freely available online

- High visibility within the field

- Retaining the copyright to your article

Submit your next manuscript at $>$ springeropen.com 